\title{
Research on the Surface Characteristics and Color Reproduction of Tissue Paper for Puer Tea Packaging
}

\author{
Ying $\mathrm{Li}^{1, \mathrm{a}}$, Jie Zhang, Wenjuan $\mathrm{Gu}^{1}$ and Banggui $\mathrm{He}^{1}$ \\ ${ }^{1}$ Faculty of Mechanical and Electrical Engineering, Kunming University of Science and Technology, \\ Kunming, 650093, China \\ acCorresponding author: haishanying@126.com
} Keywords: Hue error; Gray scale; efficiency; Surface characteristics; Mechanical properties;
Tissue paper

\begin{abstract}
A kind of tissue paper used in industrial applications for Puer tea packaging was studied. The properties of tissue paper surface which were detrimental to printability were tested. Particular attention was paid to pore rate which was affected mainly by the structure of tissue paper surface and to find correlation between their surface properties and their printability. Tissue paper for Puer tea packaging should have high pore rate because Puer tea needs ferment. Results indicated that tissue paper had a high pore rate and pores on the tissue paper arrange compactly without order. Tissue paper was printed with offset fast-drying inks to examine the conditions of color reproduction. The immediate objective of this study was to investigate surface properties of tissue paper and printability and to find which kind of press product tissue paper adapted to.
\end{abstract}

\section{Introduction}

Paper printability is variable property which is according with press conditions and printing characters [1-3]. Tissue paper for Puer tea packaging belongs to uncoated paper and fibers arrange out of order and sparsely. Tissue paper has good toughness, water absorbency, vapor permeability and pliancy. These characteristics make tissue paper adapt to Puer tea packaging. Printing process becomes difficult because tissue paper fibers range sparsely and have too strong ink absorption. When inks from plate meet substrates, a colored organic pigment in inks will penetrate into tissue paper rapidly. Studies of the effect of the coating pore structure on ink setting rate have been widely published in recent years [4-7]. But tissue paper printing can not form a certain ink film thickness and get perfect optical density. Colors of print image will become dim, and multi-color printing occur bad trapping easily. The main aim of our study was to obtain the surface properties of tissue paper and printability and to find which kind of press product tissue paper adapted to.

\section{Experimental}

Materials. Four kinds of tissue paper were used in our study which had different base weight. Proofing inks were offset printing fast-drying inks which were cyan, magenta, yellow. Overprint vanish was also offset printing fast-drying ink.

Apparatus. The characteristic properties of tissue paper substrates were measured according using the following instruments: tensile strength tester, paper thickness gauge, paper grammage tester, bursting tester, tearing strength tester, reflection densitometer X-Rite 530(USA).Tissue paper printability was measured using reflection densitometer X-Rite 530(USA).

Preparation of Printing Strips. Ink was transferred onto the tissue paper strips using a laboratory printing tester (model IGT Global standard Tester 2, America) and ink distribution apparatus (model IGT Speed Inking Unite 4) with a printing pressure of 500N and a printing speed of $0.2 \mathrm{~m} / \mathrm{s}$. The amount of ink transferred onto the ink distributing roller using IGT ink injector was $0.3 \mathrm{ml}$ and the compensation was $0.075 \mathrm{ml}$ every time. The offset printing was carried out under the following conditions.

-Printing speed $=0.2 \mathrm{~m} / \mathrm{min}$

$\bullet$ Printing Pressure=500N 
$\bullet$ Printing length $=200 \mathrm{~mm}$

-Printing width $=50 \mathrm{~mm}$

Temperature $=22^{\circ} \mathrm{C}$

$\bullet$ Humidity $=65.5 \%$

Methods. Tissue paper samples were air-conditioned before measurements, which were carried out under the same conditions. Base weight of tissue paper samples which were applied to the study of printability was $80 \mathrm{~g} \mathrm{~m}^{-2}$. Tissue paper samples were printed under the same conditions. The blanket performed the transfer of four-color offset inks onto the tissue paper samples. Proof inks were offset printing fast-drying inks which were cyan ink, magenta ink, yellow ink. Each tissue paper sample included three-color controller strips. Each color controller strip included five kinds of printing areas in which dot area coverage were 20\%, 40\%, 60\%, 80\% and 100\%. The optical density of printed tissue paper samples was measured after $24 \mathrm{~h}$ applying reflection densitometer X-Rite 530(USA).

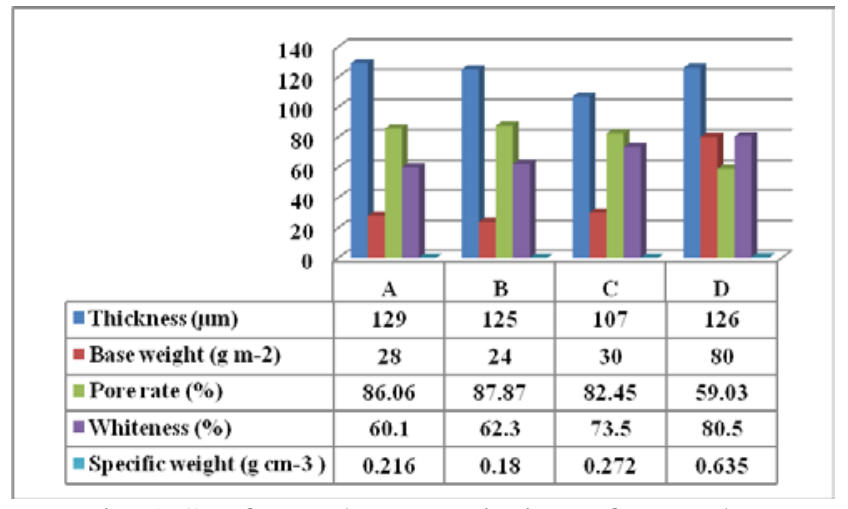

Fig.1 Surface characteristics of samples

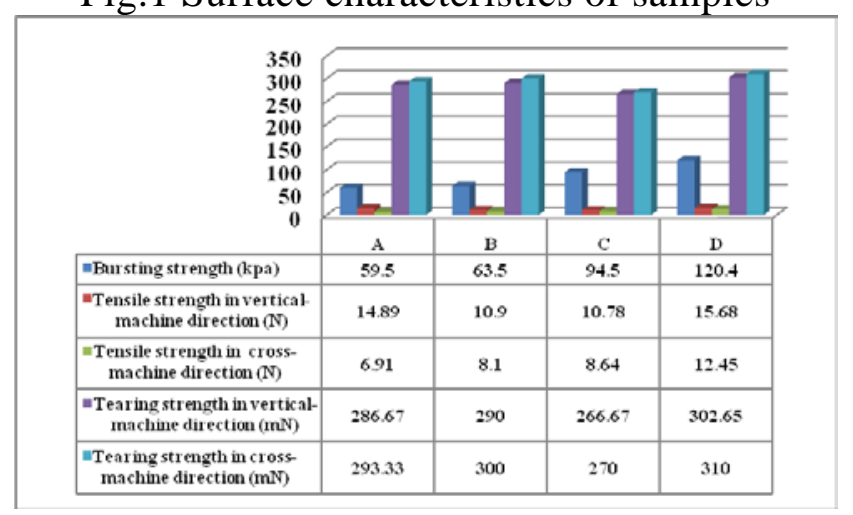

Fig.2 Mechanical properties of samples

\section{Results and discussion}

Characterization of tissue paper. Fig.1 and Fig.2 summarizes the evaluated mean values of thickness, base weight, compactness, pore rate, whiteness degrees, bursting strength, Tensile strength and tearing strength for the tissue paper materials used in the study along with the standard specification used for the evaluation(calculated from seven measurements) of properties for tissue paper materials. The results obtained were explored as the basis for discussion about the efficiency of ink transfer onto the tissue paper substrates. Four kinds of tissue paper samples had different base weight. Low base weight sample had the low compactness. Results indicated that tissue paper had the apparent differences of surface properties with the common packaging paper materials. Tissue paper fibers arranged out of order so that the value of longitudinal tearing strength was almost consistent with the value of transverse tearing strength. Results showed that tissue paper had a high pore rate and too strong ink absorption because pores on the tissue paper arrange sparsely without order. The differences of tensile strength and tearing strength between cross-machine direction and vertical-machine direction were not apparent, which reduced the influence of orientation of tissue paper fiber on 
registration accuracy.

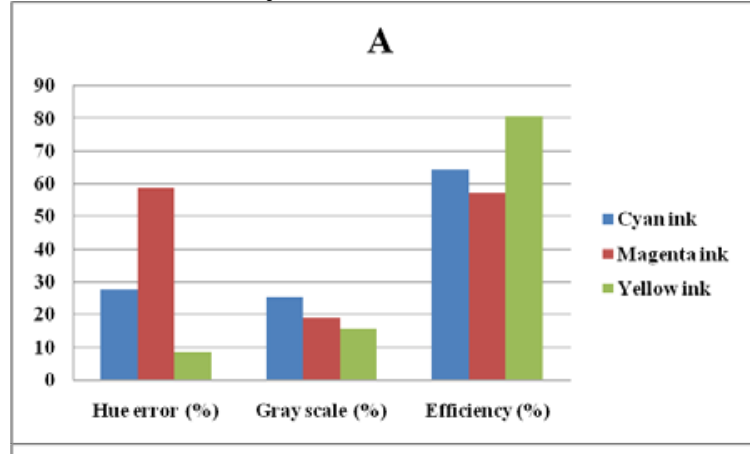

C

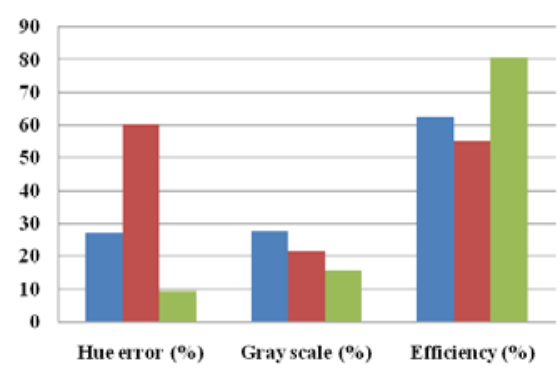

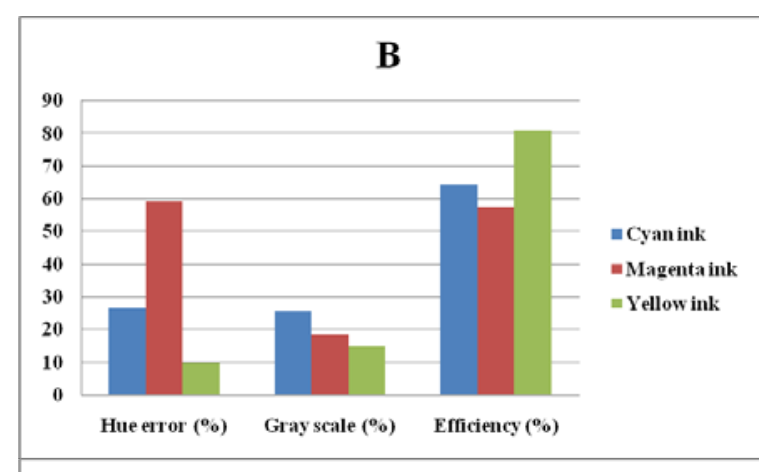

D

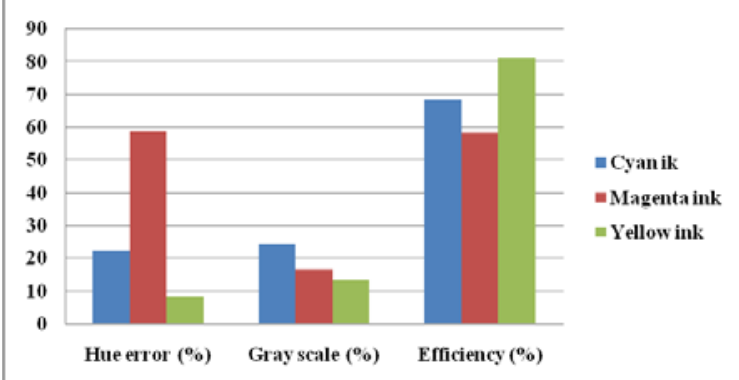

Fig.3 Hue error, gray scale, efficiency for the tissue paper materials used in the study of color reproduction

Color reproduction of tissue paper. The formation of the ink film onto the paper substrates by printing process is substantially influenced by paper-ink interactions. Consequently, the color reproduction of tissue paper materials can be obtained by analyzing the process of inks transfer onto tissue paper. The observed optical density of the ink film was a significant parameter. Color reproduction of tissue paper may be described by hue error, gray scale, efficiency which are the characteristic parameters of ink transferred onto paper materials. Three different density values can be got when color inks are tested by three-color filter.

Hue error $=\frac{M-L}{H-L} \quad(1)$

Gray scale $=\frac{L}{H}$

Efficiency $=1-\frac{M+L}{2 H}$

Where $\mathrm{H}$ is the maximal value of optical density, $\mathrm{M}$ is the middle value of optical density, $\mathrm{L}$ is the minimal value of optical density.

Fig. 3 shows the characteristic parameter values of cyan, magenta, yellow inks printed onto tissue paper. The results reflected the differences in properties of tissue paper materials. The values of hue error, gray scale of sample D were the lowest in these tissue papers. Ink efficiency of sample D was the best compared with the other tissue paper samples. The results showed inks printed onto low pore rate of tissue paper had absolute color quality and fresh color. Hue error, gray scale and efficiency may be improved by increasing the compactness of tissue paper. It can be concluded that pore rate and compactness can influence the surface properties of tissue paper and color reproduction.

\section{Conclusions}

The work has shown the properties and printability of tissue paper. Tissue paper has high pore rate and tearing strength. The differences of tensile strength and tearing strength between cross-machine direction and vertical-machine direction are not apparent, which reduce the influence of orientation of tissue paper fiber on Registration accuracy. Color reproduction of sample D is better than the others. The formation of the ink film onto the paper substrates by printing process is 
substantially influenced by paper-ink interactions. Paper properties are important factors. Tissue paper fibers arrange sparsely and out of order, which lead to high pore rate on the surface of tissue paper. Ink penetrates easily into the internal of tissue paper and can not set on the surface of tissue paper to form a certain ink film thickness.

\section{Acknowledgements}

The authors express their gratitude to the Yunnan Province Science and Technology Department (Project KKSY 2012/01059 and KKSY 2012/01051) for financial support.

\section{Reference}

[1] Bohuslava Havlı'nova', L'udmila Horn`a'kova', Vlasta Brezova', Zuzana Lipta'kova', Juraj Kindernay, Viera Janc`ovičova', Ink receptivity on paper - characterization of paper materials,Colloids and Surfaces A: Physicochemical and Engineering Aspects 168 (2000) 251-259.

[2] S. Rousu, P.A.C. Gane, D. Speilmann: Nordic Pulp Paper Res. J. 15 (5) (2001), p.527.

[3] J.S. Preston, N.J. Elton, A. Legrix, C. Nutbeem: Proceeding of TAPPI Advanced Coating Fundamentals Symposium, San Diego, May 2001.

[4] M.T. Prykäri, E. Alarousu, H. Koivula, M. Myllys, A. Lähteelä, M. Toivakka, J. Timonen, R. Myllyl"a and K.-E. Peiponen: Colloids Surf., A299 (2007)p.101.

[5] P. Heikkil€a and N. Milosavljevic: Drying Technology 20 (1) (2002), p.211.

[6] G. Udupa, M. Singaperumal, R.S. Sirohi, M.P. Kothiyal, Meas. Sci. Technol. 11 (2000), p.315.

[7]C. M. Tåg, M. Juuti, K. E. Peiponen, J.B. Rosenholm, Colloids Surf. A 317 (2008), p.658. 